\title{
STATE OF THE ART: DYNAMIC VOLTAGE RESTORER FOR POWER QUALITY IMPROVEMENT
}

\author{
Rakeshwri Pal $^{1}$, Dr. Sushma Gupta ${ }^{2}$ \\ ${ }^{1}$ Research scholar, Department of Electrical Engineering, MANIT, Bhopal, M. P., India \\ ${ }^{2}$ Associate Professor, Department of Electrical Engineering, MANIT, Bhopal, M. P., \\ India
}

\begin{abstract}
Improved and controlled power quality is one of the essential and fundamental need in any power driven industry for optimum utilization of resources. However critical problems in power quality have been recognized such as sags, swells, harmonic distortions and other interruptions. Out of these sags and swells are predominantly found and have severe impact on the electrical devices or electrical machines and therefore needs to be compensated at an earliest to ensure any mal-operation or failure. To crack these problems custom power devices are used like unified power-quality conditioner (UPQC), distributionSTATCOM (DSTATCOM) and dynamic voltage restorer (DVR). The DVR is a one of the custom power device used for the compensation of voltage sag and swell with an advantage of active/reactive power control. A major volume of literature reported in past several years on different configurations of DVR and different control technique used in it. In context of this a detailed review on DVR has been presented with different possible power circuit topologies and control techniques available to reconcile these power quality issues. This review article will contribute in better selection of control strategy and power circuit for optimum performance of DVR for a particular requirement. Also it presents a very helpful investigation for the researcher in this field.
\end{abstract}

\section{KEYWORDS}

DVR, Power system, Power quality, Voltage sag, Compensation Technique.

\section{INTRODUCTION}

Power quality is of immense importance in all modern environments where electricity is involved. Power quality can be essentially influenced by important factor like quality service. Power quality problems were categorized by five major events; sags, swells, transients, interruptions and harmonics. These problems may cause degradation in services which can cost economic losses to both utility and consumers. Deregulating of electric power system market has made power quality a parameter of consideration to achieve a higher price per kilowatt, to increase the revenue and share of the market [1]. The power quality problems emanate from various events ranging from switching events at the end user facility or faults on transmission lines [2]. The extensive use of equipment sensitive to voltage deviation has made industrial applications more susceptible to voltage sags and swells. Among these the sags appeared as a top issue [3]. Voltage sags can cause improper functioning and eventual tripping of industrial equipment, resulting in loss of production and hence profit [4-5]. There are two general approaches to mitigate power quality disturbances. One approach is to ensure that the process equipment is less responsive to disturbances, allowing it to ride-through the disturbances [6]. The other approach is to install a custom power device to suppress or neutralize the disturbances at the 
customer end. The DVR is one of most effective and efficient custom power device, which is used in power distribution systems [7]. The DVR is a power electronic device used to inject voltage in series with distribution feeder in order to compensate for voltage sag/swell. To restore the load voltage, active and/or reactive power should be injected into the distribution feeder [8]. This paper will provide an insight on various power quality problems and introduce custom power device DVR for mitigation of such problems.

\section{Power Quality}

Any power problem manifested in voltage, current or frequency deviations that result in failure or mal-operation of customer equipment [2].

\subsection{Power quality issues}

There are wide ranges of power quality problem; each of these may have a variety of different causes, different effects and different solutions that can be used to improve the power quality and equipment performance. Table 1 show different power quality issues, its causes and effects [1-2], [4-6], [8-12].

Table 1 Power Quality Issues, Its Causes And Effects

\begin{tabular}{|c|c|c|c|}
\hline \multicolumn{2}{|c|}{ POWER QUALITY ISSUES } & CAUSES & \multirow[b]{2}{*}{\begin{tabular}{l}
\multicolumn{1}{c}{ EFFECTS } \\
Tripping, \\
Processing error, \\
Data loss, and \\
Hardware reboot \\
required, \\
Component \\
failure.
\end{tabular}} \\
\hline $\begin{array}{l}\text { TRANSIENT: "Transient is } \\
\text { a sudden, non power } \\
\text { frequency change in steady } \\
\text { state condition of voltage, } \\
\text { current or both". }\end{array}$ & & $\begin{array}{l}\text { Lightning, } \\
\text { Turning major } \\
\text { equipment on or } \\
\text { off, back to } \\
\text { back capacitor } \\
\text { energization. }\end{array}$ & \\
\hline $\begin{array}{l}\text { VOLTAGE SAG: "A sag is } \\
\text { decrease to between } 0.1 \text { and } \\
0.9 \text { pu in rms voltage or } \\
\text { current at the power } \\
\text { frequency for durations } \\
\text { from } 0.5 \text { cycle to } 1 \text { min". }\end{array}$ & & $\begin{array}{l}\text { Starting of large } \\
\text { Motors, } \\
\text { Energization of } \\
\text { heavy loads, } \\
\text { Incorrect VAR } \\
\text { compensation. } \\
\text { Faults on the } \\
\text { transmission or } \\
\text { distribution } \\
\text { network. }\end{array}$ & $\begin{array}{l}\text { Dim lights, Data } \\
\text { error, Shrinking } \\
\text { display screens, } \\
\text { Equipment } \\
\text { shutdown, } \\
\text { Memory loss. }\end{array}$ \\
\hline $\begin{array}{l}\text { VOLTAGE SWELL: "A } \\
\text { swell is an increase to } \\
\text { between } 1.1 \text { and } 1.8 \text { pu in } \\
\text { rms voltage or current at } \\
\text { the power frequency for } \\
\text { durations from } 0.5 \text { cycle to } \\
1 \text { min". }\end{array}$ & & $\begin{array}{l}\text { Energizing a } \\
\text { large capacitor } \\
\text { bank, Switching } \\
\text { off a large load, } \\
\text { incorrect VAR } \\
\text { compensation. }\end{array}$ & $\begin{array}{l}\text { Bright lights, } \\
\text { Data error, } \\
\text { Racing or } \\
\text { blinking of } \\
\text { digital clock. }\end{array}$ \\
\hline
\end{tabular}


Electrical \& Computer Engineering: An International Journal (ECIJ) Volume 4, Number 2, June 2015

\begin{tabular}{|c|c|c|c|}
\hline $\begin{array}{l}\text { VOLTAGE } \\
\text { INTERRUPTION: "An } \\
\text { interruption is when the } \\
\text { supply voltage or load } \\
\text { current decreases to less } \\
\text { than } 0.1 \text { pu for a period of } \\
\text { time not exceeding } 1 \mathrm{~min} \text { ". }\end{array}$ & & $\begin{array}{l}\text { Faults (Short } \\
\text { circuit), } \\
\text { Equipment } \\
\text { failures, } \\
\text { insulator failure, } \\
\text { lightning, } \\
\text { Control } \\
\text { malfunctions. }\end{array}$ & $\begin{array}{l}\text { Equipment trips } \\
\text { off, } \\
\text { Programming is } \\
\text { lost, Computer } \\
\text { shut down, Disk } \\
\text { drive crashes. }\end{array}$ \\
\hline $\begin{array}{l}\text { HARMONICS: } \\
\text { "Harmonics are integral } \\
\text { multiples of some } \\
\text { fundamental frequency that, } \\
\text { when added together, } \\
\text { results in a distorted } \\
\text { waveform". }\end{array}$ & & $\begin{array}{l}\text { IT equipment, } \\
\text { Fluorescent } \\
\text { lighting and any } \\
\text { non linear load } \\
\text { such as variable } \\
\text { frequency } \\
\text { drives, Electro- } \\
\text { Magnetic } \\
\text { Interference } \\
\text { from appliances, } \\
\text { SMPS. }\end{array}$ & $\begin{array}{l}\text { Line current } \\
\text { increases, Higher } \\
\text { losses } \\
\text { Transformer and } \\
\text { neutral conductor } \\
\text { overheating, } \\
\text { leading to } \\
\text { reduced } \\
\text { equipment life } \\
\text { span, instruments } \\
\text { malfunctioning. }\end{array}$ \\
\hline
\end{tabular}

\subsection{Power Quality Improvement Alternative}

There are variety of custom power devices available each with its own benefits and boundaries: Active Power Filters (APF), Battery Energy Storage Systems (BESS), Distribution Series Capacitors (DSC), Solid-State Transfer Switches (SSTS), Surge Arresters (SA), Super conducting Magnetic Energy Systems (SMES), Uninterruptible Power Supply (UPS), Static Electronic Tap Changers (SETC), Solid State Fault Current Limiter (SSFCL), Static VAR Compensator (SVC) and Thyristor Switched Capacitors (TSC), unified power-quality conditioner (UPQC), Distribution-STATCOM (DSTATCOM) and dynamic voltage restorer (DVR). DVR is considered as an effective and efficient custom power device for mitigating the impact of voltage disturbances on sensitive load. In addition DVR also has functions such as reactive power compensation and harmonic compensation [4] [13-15].

\subsection{Merit of DVR over other Custom Power Devices [16-22]}

- The SVC pre-dates the DVR, but the DVR is still favored because the SVC has no capability to control the active power flow.

- The DVR is small in size and price is less compared to DSTATCOM and other custom power devices.

- The DVR has more energy capacity compared to the UPS and SMES. DVR has many advantages over UPS, like less cost, higher capacity, low losses, injects only the missing part of the supply voltage and less maintenance.

- Economic comparisons of SSTS and DVR has been investigated and it reveals that SSTS provides better solution in terms of expected savings, cost of solution per KVA, annual operating cost and a higher benefit/cost ratio if, a secondary undisturbed or independent feeder is present otherwise DVR is considered to be the most cost effective solution, because SSTS does not regulate voltage neither generate/absorb reactive powers. Its only purpose is to deactivate a faulty feeder in favor of a healthy one. 


\section{Dynamic Voltage Restorer (DVR)}

The DVR (Dynamic Voltage Restorer) is a series connected solid state device that injects additional voltage into the system in order to regulate the load side voltage to the desired magnitude and waveform even when the source voltage is unbalanced or distorted as shown in figure 1 [23-24]. This process involves injection of active/reactive power from DVR to distribution feeder [25].

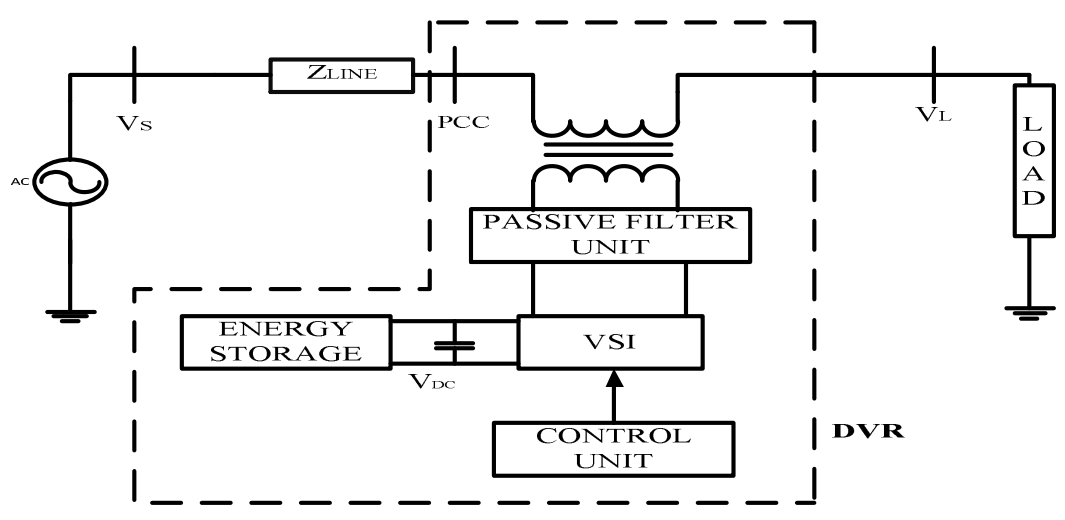

Figure 1 Basic structure of DVR

The general configuration of the DVR consists of power circuit and control circuit. Equivalent circuit as shown in Figure 2 and equation is as under:

$\mathrm{V}_{\mathrm{DVR}}=V_{L}+\mathrm{Z}_{\mathrm{TH}} \mathrm{I}_{\mathrm{L}}+\mathrm{V}_{\mathrm{TH}}$

Where $\mathrm{V}_{\mathrm{L}}$ is desired load voltage magnitude, $\mathrm{Z}_{\mathrm{TH}}$ is load impedance, $\mathrm{I}_{\mathrm{L}}$ is load current and $\mathrm{V}_{\mathrm{TH}}$ is system voltage (during faulty condition)

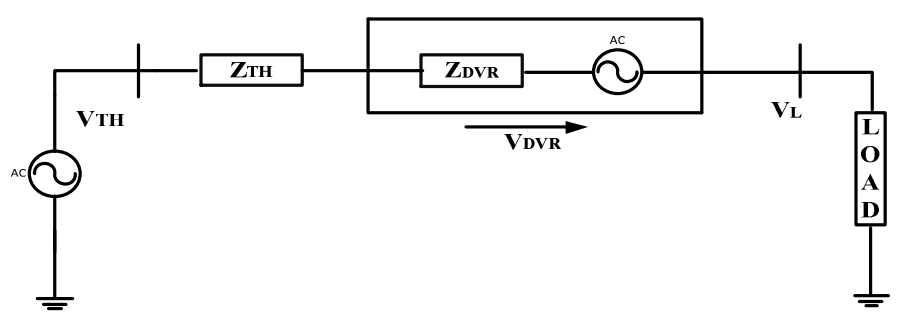

The load current $I_{L}$ is given by

Figure 2 Equivalent circuit

$I_{L}=\frac{\mathrm{P}_{\mathrm{L}}+\mathrm{jQ}_{\mathrm{L}}}{\mathrm{V}_{\mathrm{L}}}$

When $\mathrm{V}_{\mathrm{L}}$ is considered as a reference equation can be written as

$\mathrm{V}_{\mathrm{DVR}} \angle \alpha=V_{L} \angle 0+\mathrm{Z}_{\mathrm{TH}} \mathrm{I}_{\mathrm{L}} \angle(\beta-\theta)+\mathrm{V}_{\mathrm{TH}} \angle \delta$

Where $\alpha$ is angle of $\mathrm{V}_{\mathrm{DVR}}, \beta$ is angle of $\mathrm{Z}_{\mathrm{TH}}, \delta$ is angle of $\mathrm{V}_{\mathrm{TH}}$ and $\theta$ is load power angle 
$\theta=\tan ^{-1} \frac{Q_{L}}{P_{L}}$

The complex power injection of the DVR can be written as

$S_{D V R}=V_{D V R} I_{L}^{*}$

\section{LOCATION OF DVR}

The objective is only to protect one consumer or a group of consumers with value added power. Applying a DVR in the Medium Voltage (MV) or Low Voltage (LV) distribution system would often be feasible. A key difference between an MV connection and an LV connection is the generation of zero sequence voltages and the flow of zero sequence currents.

- In the four-wire LV distribution system as shown in figure 3, the DVR must secure low impedance for zero sequence currents and the zero sequence must either flow in the power converter or in a delta winding of the injection transformer [26], and the impedance introduced due to the placing of the DVR seen at the LV side is comparatively high [27].

- In the three-wire MV distribution system as shown in figure 4, in most countries makes the use of simple DVR topology and therefore relatively easy control possible since there is no zero-sequence component. The DVR requires high isolation level for the injection transformers, and the short circuit level is also high in MV level [26-27].

- Compared to the implementation at LV level, the MV implementation of DVR could achieve reduced costs per megavolt ampere [27].

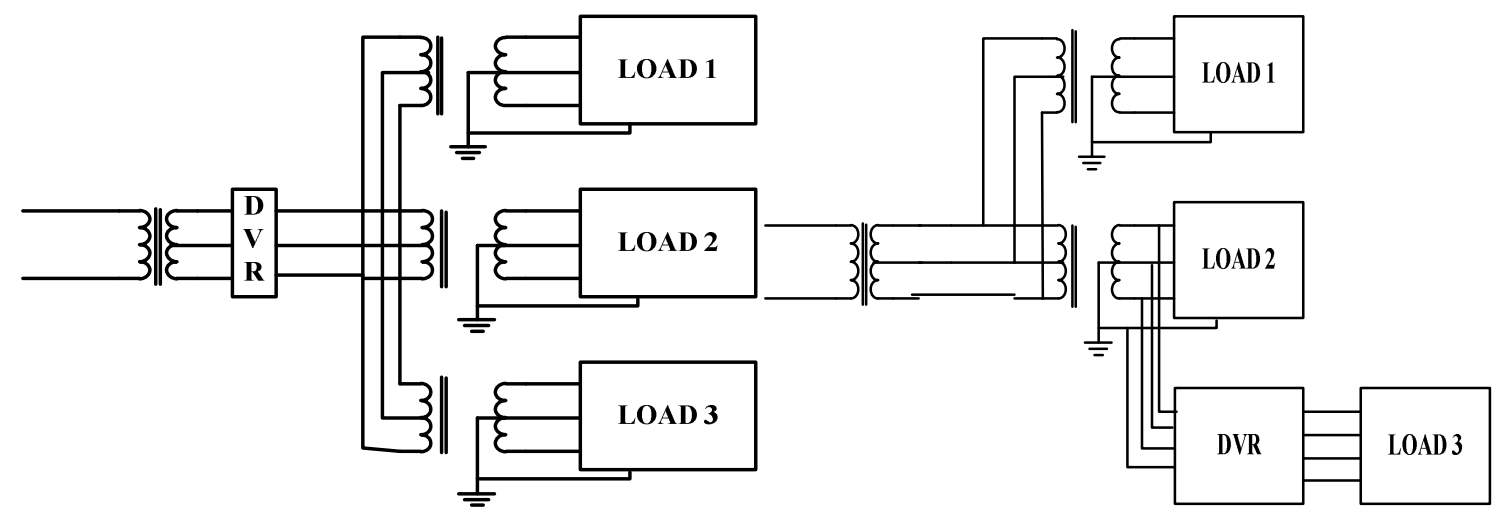

Figure 3 DVR located at the MV system

Figure 4 DVR located at the LV system

\section{Power Circuit}

In basic DVR topology, power circuit of DVR consists of an injection/booster transformer, a harmonic filter, an energy storage device, a voltage source inverter and a bypass switch.

\subsection{Injection / Booster transformer}

The basic function of the injection transformer is to connect the DVR to the distribution network via the $\mathrm{HV}$-windings and couples the injected compensating voltage generated by Voltage Source 
Inverter (VSI) to the incoming supply voltage after the detection of any voltage disturbance by the control circuit. The injection transformer increases the voltage supplied by the filtered VSI output to the desired level, in addition it serves the purpose of isolating the DVR circuit from the distribution network [28]. For single phase DVR one single-phase transformer is connected and for a three phase DVR, three single-phase transformers or a single three phase transformer can be connected either in delta/open or star/open configuration. The winding configuration of the injection transformer is very important and it mainly depends on the upstream distribution transformer.

- If delta-star transformer is used in distribution feeder, zero-sequence voltages will not circulate through the transformer when earth faults occur on the higher voltage level. Therefore, restoration of positive sequence and compensation of negative voltage are necessary [29]. Hence, a delta-open injection transformer can be used. The delta/open winding as shown in figure 5 maximizes the utilization of DC link voltage [30].

- If an earthed star-star distribution circuit transformer is used, zero sequence voltages have to be compensated [29]. For this case, a star-open injection transformer as shown in figure 6 is used with injection of zero sequence voltages from the DVR [31].

The transformer ratio can be sized to have maximum utilization of the converter. The rating of the injection transformer is an key factor when deciding the DVR performance, since it limits the maximum compensation capability of the DVR [32], if the transformer is under rated the injected voltage may saturate the transformer and result in improper operation of the DVR, this problem can be solved by over rated transformer, however this increases the overall size and price of the DVR. [33].

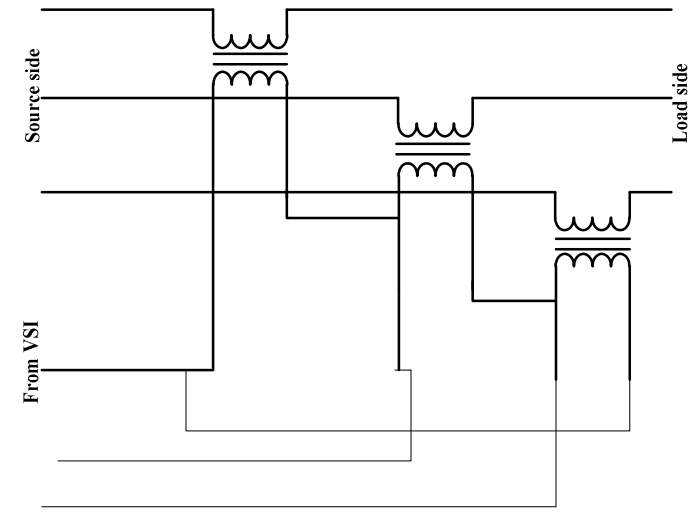

Figure 5 Delta open configuration

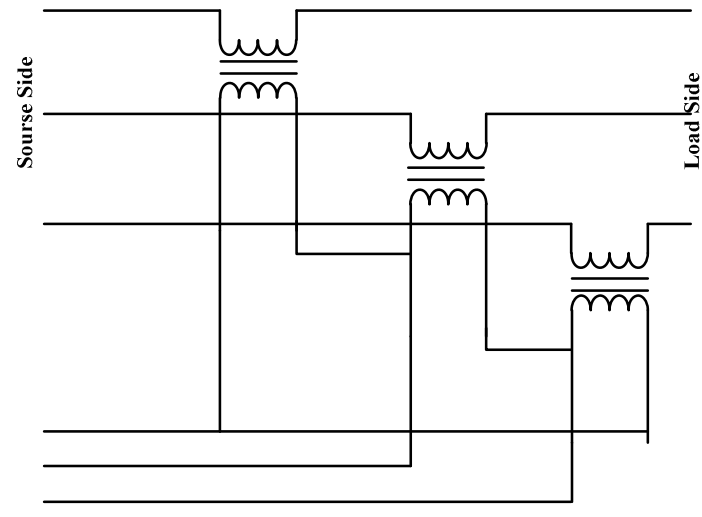

Figure 6 Star open Configuration

\subsection{DC-link and Energy Storage Devices}

The DC-link and energy storage device provides the real power requirement of DVR during compensation. The required energy can be taken from an auxiliary supply (topologies with energy storage) or grid itself (topologies with no energy storage) for compensation of load voltage during sag.

- The auxiliary supply system is used to raise the performance when the grid of DVR is weak. In this type, constant DC link voltage or variable DC link voltage topologies are used. 
Flywheels, batteries, superconducting magnetic energy storage (SMES) and super capacitors can be used in auxiliary supply system.

- In grid connected topology if grid is strong, the remaining voltage on supply side or load side is used to supply required power to the DVR, in this method AC/DC/AC converter is used.

If the topologies are compared by using some criterions like cost, system and control complexity, drawback and performance, they can be sequenced as [34-37]:

1- Load Side Connected Converter

2- Constant DC Link Voltage

3- Variable DC Link Voltage

4- Supply Side Connected Converter

\subsection{Voltage Source Inverter (VSI)}

VSI is a power electronics device consists of à storage devices, which can generate a sinusoidal voltage at any required frequency, magnitude and phase angle. The basic function of the VSI is to convert the dc voltage supplied by the energy storage device/dc-link into an ac voltage. The VSI used in the DVR can be two-level or multilevel.

- The two-level PWM inverter is the leading type of inverter used in DVR because implementation of the PWM in two-level inverter is simple and its cost is cheaper than multilevel inverter [28].

- The multilevel inverter has good harmonic characteristics and can operate in higher voltage levels [38]. The most popular multilevel VSI topology is cascaded H-bridge (CHB) VSI. Apart from the CHB topologies, other multilevel inverters such as the neutral point clamped (NPC) multilevel inverter, and the flying capacitor multilevel inverter have also been used in the DVR structure [38-42].

In the DVR power circuit step up voltage injection transformer is used therefore a VSI with a low voltage rating is adequate [41].

\subsection{Harmonic filter}

The main purpose of the harmonic filter is to maintain the harmonics content generated by the VSI to the permissible level. The filter is placed to damp the switching harmonics generated by the PWM control of VSI. If the modulation index is set below one, the switching harmonics are normally centered around the switching frequency and multiples of the switching frequency [43]. These filters can be inserted either in low voltage (inverter) side or in the high voltage (load) side of the injection transformer [44].

- The higher order harmonics are prevented from penetrating into transformer if filter is placed at inverter side, in this manner it reduce the voltage stress on the transformer. But there can be a phase shift and voltage drop in the output, which can disrupt the control strategy [45-46].

- By placing the filter at the load side phase shift cannot be take place but harmonics can penetrate into the high voltage side of the transformer, a higher rating transformer is required [43].

On the other hand the leakage reactance of the transformer can be used as a part of the filter, which will be supportive in tuning the filter [47]. 


\subsection{By-pass Switch}

The DVR is a series connected device and one of the drawbacks with series connected devices is the difficulties to protect the device during short circuits and avoid interference with the existing protection equipment. During overload, faults and at time of maintenance an alternative path for the load current has to be ensured. Generally a crowbar by-pass switch is used which bypasses the inverter circuit [28].

\section{MODES OF OPERATION OF DVR}

\subsection{Protection mode}

During fault, the DVR is protected from the high current in the load side due to short circuit on the load or large inrush currents the DVR will be isolated from the system by using bypass switches (S2 and S3 will open) and providing an alternative path for current (S1 will be closed) as shown in figure 7 [22].

\subsection{Standby mode $\left(V_{\text {DVR }}=0\right)$}

During normal operation, the DVR may either go into short circuit operation which is called standby mode or inject small voltage to compensate the voltage drops on transformer reactance or losses. Generally standby mode is preferred [22], [48].

\subsection{Injection/boost mode $\left(\mathrm{V}_{\mathrm{DVR}}>0\right)$}

As soon as sag is detected the DVR goes into injection mode. AC voltage is injected in series with required magnitude, phase and wave shape for compensation [22].

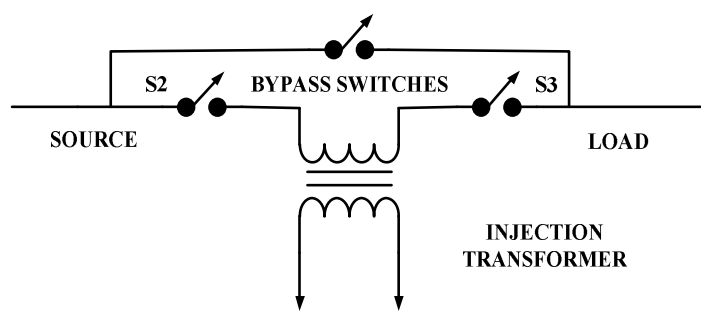

Figure 7 Mode of operation

\section{VOLTAGE INJECTION/COMPENSATION TECHNIQUES OF DVR}

\subsection{Pre-sag compensation method}

In this method DVR keeps load voltage phasor unchanged in relation to that before the disturbance. This compensation strategy is recommended for the non linear load; i.e. sensitive to phase angle jump. It restores both the voltage sag and the phase jump. It avoids any circulating or transient current at load side. It needs active power during compensation [49-53]. 


\subsection{In-phase compensation method}

In this method DVR injects its voltage in phase with supply voltage. This compensation strategy is recommended for the linear load, where voltage magnitude is only required for compensation. Therefore amount of the injected voltage is minimal due to which the voltage rating of the dc link is minimal. It needs active power during compensation. It can't restore the phase jump [49-53].

\subsection{In-phase advanced/Energy optimization compensation method}

In this method injected voltage advances the voltage, so the injected voltage phasor and line current are perpendicular. In case of pre-sag and In-phase the DVR is required to insert real power into the faulty line during the compensation period, the capacity of the energy storage device can become a limiting factor in the compensation. The real power is stored in the DC link and this is one of the most expensive parts of DVR. The basic idea of energy optimization method is to make the injected real power component zero by having the injection voltage phasor perpendicular to the load current phasor [49-58]. In this method value of load current and voltage are fixed in the system so we can alter only the phase of sag voltage. It uses only reactive power during compensation, reactive power is generated electronically from within the voltage source inverter (VSI) [57-88], hence higher rating of VSI required. Unfortunately, all the sags cannot be mitigated without real power; as a consequence this method is only suitable for a limited range of sags. Performance of different compensation techniques are tabulated in table 2.

Table 2 Performance of Different Voltage Compensation Techniques of DVR

\begin{tabular}{|c|c|c|c|}
\hline Parameters & Pre-sag & In phase & In phase advanced \\
\hline $\begin{array}{l}\text { Recommended } \\
\text { load }\end{array}$ & Non-linear load & Linear load & Linear load. \\
\hline Phasor & $\underset{\text { Iraxt }}{\longrightarrow}$ & & $K_{\text {Ilo }}$ \\
\hline Restore & $\begin{array}{l}\text { Voltage magnitude and } \\
\text { phase angle }\end{array}$ & $\begin{array}{l}\text { Only voltage magnitude } \\
\text { not phase angle }\end{array}$ & $\begin{array}{l}\text { Only voltage magnitude } \\
\text { not phase angle. }\end{array}$ \\
\hline $\begin{array}{l}\text { Rating of } \\
\text { storage device/ } \\
\text { Voltage } \\
\text { injection } \\
\text { transformer/I } \\
\text { nverter }\end{array}$ & $\begin{array}{l}\text { Higher rated storage } \\
\text { device and voltage } \\
\text { injection transformer }\end{array}$ & $\begin{array}{l}\text { Minimum rated storage } \\
\text { device and voltage } \\
\text { injection transformer }\end{array}$ & Higher rating of inverter. \\
\hline
\end{tabular}


Electrical \& Computer Engineering: An International Journal (ECIJ) Volume 4, Number 2, June 2015

\begin{tabular}{|c|c|c|c|}
\hline $\begin{array}{l}\text { Performance } \\
\text { of PLL during } \\
\text { load }\end{array}$ & $\begin{array}{l}\text { PLL is synchronized } \\
\text { with load voltage, when } \\
\text { a failure occurs, the } \\
\text { PLL will be locked and } \\
\text { phase angle can be } \\
\text { restored as earliest. }\end{array}$ & $\begin{array}{l}\text { PLL has to be } \\
\text { synchronized with grid } \\
\text { voltage; therefore PLL } \\
\text { will not be locked } \\
\text { during } \\
\text { compensation. }\end{array}$ & $\begin{array}{l}\text { PLL has to be } \\
\text { synchronized with grid } \\
\text { voltage; therefore PLL } \\
\text { will not be locked during } \\
\text { the compensation. }\end{array}$ \\
\hline $\begin{array}{l}\text { Magnitude of } \\
\text { injected } \\
\text { voltage } \\
\end{array}$ & High. & Minimum. & $\begin{array}{l}\text { Quite high compared to } \\
\text { pre-sag and in phase } \\
\text { methods. }\end{array}$ \\
\hline Distortion & $\begin{array}{l}\text { Technique leads to } \\
\text { lowest distortion. }\end{array}$ & $\begin{array}{l}\text { Distortion due to phase } \\
\text { change is not } \\
\text { minimized. }\end{array}$ & - \\
\hline Reliability & $\begin{array}{l}\text { This technique is } \\
\text { reliable to protect } \\
\text { sensitive loads without } \\
\text { having any transient and } \\
\text { circulating current. }\end{array}$ & $\begin{array}{l}\text { This technique leads to } \\
\text { transient and circulating } \\
\text { current. }\end{array}$ & $\begin{array}{l}\text { This technique sometimes } \\
\text { leads to unwanted phase } \\
\text { shift when compensated } \\
\text { for voltage sag. }\end{array}$ \\
\hline $\begin{array}{l}\text { Active/Reactiv } \\
\text { e power } \\
\text { requirement }\end{array}$ & $\begin{array}{l}\text { Active and reactive } \\
\text { power. }\end{array}$ & $\begin{array}{l}\text { Active and reactive } \\
\text { power. }\end{array}$ & Only reactive power. \\
\hline $\begin{array}{l}\text { Outcomes of } \\
\text { strategy }\end{array}$ & $\begin{array}{l}\text { It eliminates the voltage } \\
\text { disturbance completely } \\
\text { even if the phase jumps } \\
\text { of voltage in each phase } \\
\text { are different. }\end{array}$ & $\begin{array}{l}\text { It does not eliminate } \\
\text { voltage } \\
\text { completely }\end{array}$ & $\begin{array}{l}\text { It does not eliminate } \\
\text { voltage } \\
\text { completely }\end{array}$ \\
\hline $\begin{array}{l}\text { Compensation } \\
\text { against } \\
\text { balanced/unba } \\
\text { lanced load }\end{array}$ & $\begin{array}{l}\text { It can compensate both } \\
\text { balanced and } \\
\text { unbalanced voltage sag. }\end{array}$ & $\begin{array}{l}\text { It can compensate both } \\
\text { balanced and } \\
\text { unbalanced voltage sag. }\end{array}$ & - \\
\hline
\end{tabular}

Essentially the type of load connected influences the compensation method.

\section{Control Circuit}

In DVR the control circuit is used to derive the parameters such as magnitude, frequency, phase shift etc. Control of compensating device is implemented in 3 steps, detection of voltage $\mathrm{sag} / \mathrm{swell}$ occasion in the system, comparison with reference value and generation of gate pulses to the VSI to generate the DVR output voltages which will compensate the voltage sag/swell.

\subsection{Sag/Swell Detection Techniques}

The accurate detection and classification of disturbances can help in taking effective countermeasure(s) to maintain adequate power quality. To detect the voltage sag, the starting point and the ending point of sag, depth of sag and phase shift, information are required. There are some detection techniques which are summarized below: 


\subsubsection{Fourier Transform (FT) method}

To achieve the FT we use the orthogonal decomposition of power system signal. When we apply the FT to each supply phase, it is possible to get the magnitude and phase of each of the frequency components of the supply waveform. The demerit of FT is that it takes one complete cycle to give the accurate information about the sag depth and its phase. The realization in real time control is possible [59-61], [65-66].

\subsubsection{Phase Locked Loop (PLL) method}

PLL is applied to each supply phase independently and is tuned to respond to phase jumps in the supply quickly. In this method it is required to freeze the pre-sag magnitude and phase. The PLL generates the voltage in same phase with the supply voltage. It takes time delay up to half cycle. The implementation in real time control system is more difficult [59-61].

\subsubsection{Peak value detection method}

Peak detection method is the very simplest method to observe the crest of the supply voltage. In this we find the point where the gradient of supply voltage phases is zero, and then we compare the supply value at that instant with a reference value and sense the sag. A controller could be set to distinguish if there is a deviation greater than a specified value. This method provides the information of sag depth, start and end time, although to extract phase shift information is difficult since a reference waveform is required. The drawback of this method is that it can take up to half a cycle for the sag depth information to become available [59-61].

\subsubsection{Root mean square (RMS) method}

It detects the start and end points of sag/swell. RMS value detection is an accurate way to detect the voltage sag or interruption, but it does not give phase angle shift information. It takes more time to calculate the RMS value [62-65].

\subsubsection{Space Vector control}

This method gives the both voltage magnitude and angle shift information. Three phase voltages $\mathrm{V}_{\mathrm{a}}, \mathrm{V}_{\mathrm{b}}, \mathrm{V}_{\mathrm{c}}$ are transformed into a two dimension voltage $\mathrm{V}_{\mathrm{d}}, \mathrm{V}_{\mathrm{q}}$ which in turn can be transformed into magnitude and phase angle. It is faster but requires complex controller. This can be easily realized in real time control system [59-61].

\subsubsection{Wavelet Transform (WT) method}

WT performs better with non-periodic and non-stationary signals. It detects change in the state of the supply phases quickly. In wavelet analysis procedure we design a wavelet prototype function, or the mother wavelet. The disadvantage of this method is selection of appropriate mother wavelet for each application, since the related filter bank coefficients are dependent on selected mother wavelet. There is also a delay associated with many mother wavelets as data either side of a time instant may be required in the convolution process. The implementation in real time control is difficult [59-61], [66-68]. 


\subsubsection{Control Strategies}

The inverter control strategy includes of two types of control linear and non linear.

\subsubsection{Linear Controller}

The linear controllers used in DVR are feed forward, feedback and composite control. The comparison among these controllers is tabulated in Table 3.

\subsubsection{Feed forward}

The feed forward controller is the prime option for the DVR, because of its ease and fastness. The feed forward control technique does not sense the load voltage rather it calculates the injected voltage on the basis of the difference between the pre-sag and during-sag voltages. The drawback of this controller is the high steady state error [69-70].

\subsubsection{Feed back}

The feedback controller measures the load voltage and the difference between the voltage reference of the load and actual load voltage is injected. The feedback controller has the benefit of exact response, but it is complex and time-delayed [69-70].

\subsubsection{Composite}

Composite control strategy is a control method with grid voltage feed forward and load side voltage feedback, which has strength of feed forward and feedback control strategies. If the feedback control in the composite control is designed to double-loop, it can improve system stability, system performance and the adaptability of dynamic load. The combination with feed forward control can improve the system dynamic response rate, shortening the time of compensation significantly [70].

Table 3 Comparison of different linear controllers

\begin{tabular}{|l|l|l|l|}
\hline \multicolumn{1}{|c|}{ Parameter } & \multicolumn{1}{|c|}{ Feed forward } & \multicolumn{1}{|c|}{ Feed back } & \multicolumn{2}{c|}{ Composite } \\
\hline Measures & Grid voltage & Load voltage & $\begin{array}{l}\text { Grid voltage feed } \\
\text { forward and load side } \\
\text { voltage feedback }\end{array}$ \\
\hline Response time & $\begin{array}{l}\text { Fast, dependent on } \\
\text { system }\end{array}$ & $\begin{array}{l}\text { Medium } \\
\text { controllable through } \\
\text { controller }\end{array}$ & Can be eliminated \\
It has strength of \\
feedforward and \\
feedback both.
\end{tabular}


Electrical \& Computer Engineering: An International Journal (ECIJ) Volume 4, Number 2, June 2015

\begin{tabular}{|l|l|l|}
\hline $\begin{array}{l}\text { Switching } \\
\text { harmonics }\end{array}$ & $\begin{array}{l}\text { Do not enter the } \\
\text { control }\end{array}$ & Enter the control \\
\hline $\begin{array}{l}\text { Compensation of } \\
\text { non-symmetrical } \\
\text { fault }\end{array}$ & Slow, possible & Good \\
\hline $\begin{array}{l}\text { Load voltage } \\
\text { distribution at non- } \\
\text { linear loads }\end{array}$ & High & Can be reduced \\
\hline
\end{tabular}

\subsubsection{Non -Linear Controller}

The DVR is a non-linear device due to the power semiconductor switches in the inverter circuit. It appears that the nonlinear controller is more appropriate than the linear type since the DVR is actually a non-linear system.

\subsubsection{Fuzzy Logic (FL)}

FL controllers are an attractive alternative when precise mathematical formulations are not feasible. When it is used, the tracking error and transient overshoots of PWM can be significantly reduced. However, the properties of the FL controller are very susceptible to any change of fuzzy sets shapes and overlapping. Consequently, the designing and performance strongly depends on the knowledge and expertise of the designer [70-73].

\subsubsection{Artificial Neural Network (ANN)}

The ANN has adaptive and self-organizing capacity that gives improved precision by interpolation. It can institute the nonlinear relationship based on input and output, without the mathematical model [29] [70] [74].

\subsubsection{Space Vector Pulse Width Modulation (SVPWM)}

In SVPWM we adopt a voltage inverter space vector of the switch to get quasi-circular rotating magnetic field as an alternative of the original Sinusoidal PWM, so that improved performance of the switch over is achieved in low switching frequency conditions. The SVPWM method is an advanced, computation-intensive PWM method and probably the best among all the PWM techniques. SVPWM is used because of its easier realization and better dc bus utilization [70] [75-77].

\section{Interline Dynamic Voltage Restorer (IDVR)}

Active power capability of the DVR is governed by the capacity of the energy storage element and the employed compensation technique [78]. However, size and cost constraints of energy storage systems limits their capacity hence the DVR active power injection capability. If the required active power for voltage restoration is obtained from neighboring feeder(s), the compensating device is called an inter-line dynamic voltage restorer (IDVR) [79].IDVR consists of several DVRs on different distribution lines sharing a common DC link, it enables active power exchange between two or more DVR. This would cut down the cost of custom power device as sharing a common DC-link, reduces the DC-link storage capacity significantly and size as well [80]. As the feeders in IDVR system are emanating from different grid substations, so these feeders could be of the same voltage magnitude or different voltage 
magnitude level [81]. DVR in IDVR system works in a voltage compensation mode or in a power flow controller mode. While one of the DVRs carries out voltage compensation during sag, the other DVRs can replenish energy to the DC-link to maintain its voltage at a specific level [82]. Mitigation of voltage sag simultaneously in both feeders is not a feature of the two line IDVR as shown in figure 8 if active power is injected from DC-link capacitor. To overcome these limits, renewable energy sources and/or energy storage elements can be connected to the common DClink to share the required real power [83-85].

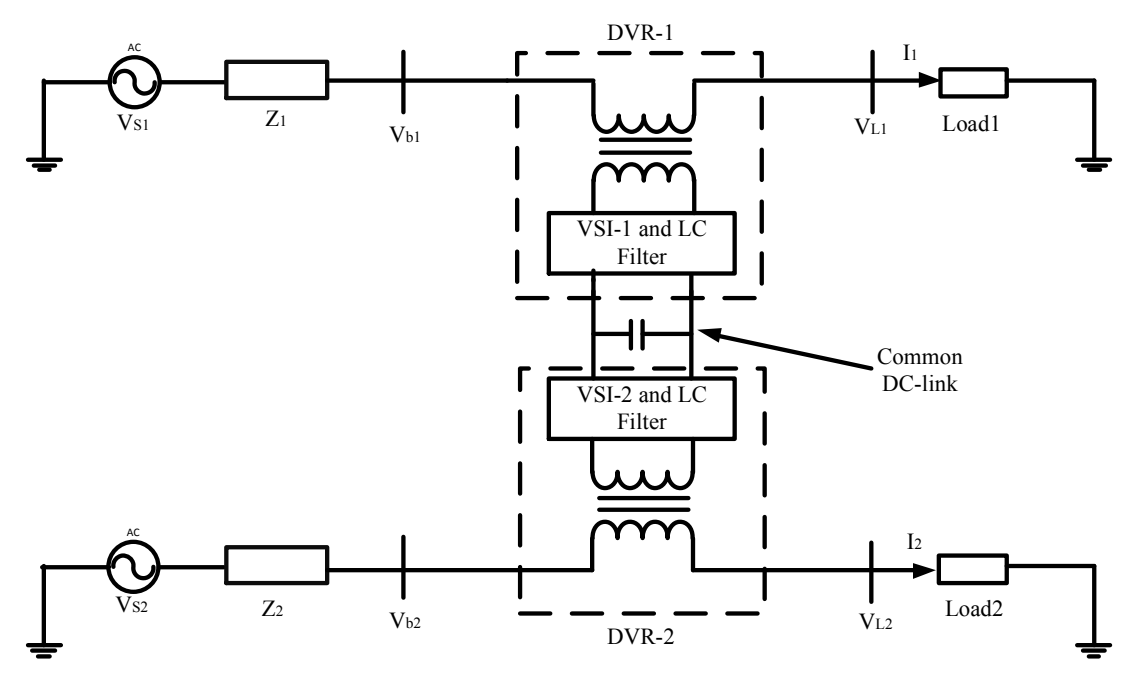

Figure 8 inter-line dynamic voltage restorer

\section{POWER CIRCUIT TOPOLOGIES ALTERNATIVES OF DVR}

\subsection{Transformer-less topology of DVR}

The transformer-less DVR has been also reported for voltage compensation. This method gets rid of the injection transformer used in the basic configuration of DVR. The major functions of the injection transformer include voltage injection and electrical isolation. Apart from its cost, it is bulky and it contributes toward the restorer losses. There can still be problems such as those pertaining to the saturation and inrush currents associated with the transformer magnetization phenomenon even when it is judiciously designed, [33] [38]. Advantages and disadvantages with the transformer-less DVR are as below [86-87]:

\section{Advantages}

- Non linear effect that is saturation and voltage drop by transformer is removed, only a small voltage drop due to switching component is present, which is normally negligible.

- Bulky transformer can be avoided, a compact solution low volume, low weight is achieved.

- Cost is less than that of when series transformer is used.

Disadvantages

- Convertor topology is more complex and higher no. of components is expected to be used.

- Protection of power electronics is more complicated and basic insulation level (BIL) must be ensured more actively. 
On ride-through capability enhancement, with the same amount of stored energy, the ride-through capability offered by the conventional and the transformer-less DVR schemes are identical under balanced three-phase voltage sags. However, the ride-through capability of the transformer-less DVR during single-phase voltage sag is only $1 / 3$ that of the conventional DVR.

\subsection{Direct AC/AC converter based topology of DVR}

This topology eliminates the need of DC-link/energy storage element. The DVR topologies are based on both conventional ac/dc/ac (DC-link) conversion and ac/ac (AC link) direct conversion. Conventional ac/dc/ac topologies are categorized into two groups. In first group the necessary dc voltage is provided through a transformer from the grid (source side or load side) via a rectifier. In the second group the necessary energy for compensation of voltage is taken from the dc capacitor or another energy storage element via an inverter. The energy storage element are the most expensive and massive part of the DVR [88-89]. Beside the conventional topologies, some topologies have been presented for DVRs which use direct ac/ac converters without need for energy storage elements and intermediate dc link [89-92]. Conventional topology usually includes a voltage source inverter (VSI) [40]. In ac/ac conversion topologies matrix converter [93-95] and Vector Switching Converter VeSC [96-98] are popularly used. Advantages and disadvantages with the AC link DVR are as below [40], [89]:

Advantages

- Less cost.

- Less weight and volume because it eliminates the use of heavy DC link capacitor (or energy storage element).

- Compensation can be accomplished for long time.

- Reduced installation area.

Disadvantages

- High no. of switches.

- Limited compensation range because operation in case of deep sags may not be successful.

\section{CONClusion}

In this paper a brief literature review is done on DVR configurations and its control strategies. By selecting any one of them we can provide solution to various power quality problems like voltage harmonics, voltage sag/swell compensation. To improve the performance of DVR, efforts needs to be made on energy savings, reduced parts and losses, minimum power injection, reduced rating, and selective harmonics mitigation.

\section{REFERENCES}

[1] IEEE Recommended Practice for Monitoring Electric Power Quality," IEEE Std 1159-1995, 1995.

[2] Roger C. Dugan, Mark F. McGranaghan, Surya Santoso, H. Wayne Beaty, "Electrical Power Systems Quality", Tata McGraw Hills publications, $3^{\text {rd }}$ Edition 2012.

[3] Venmathi, M.; Ramesh, L., "The impact of Dynamic Voltage Restorer on voltage sag mitigation," Sustainable Energy and Intelligent Systems (SEISCON 2012), IET Chennai 3rd International on, vol., no., pp.1,7, 27-29 Dec. 2012. 
Electrical \& Computer Engineering: An International Journal (ECIJ) Volume 4, Number 2, June 2015

[4] Benachaiba, C., Ferdi, B., "Power Quality Improvement Using DVR", American Journal of Applied Sciences, vol. 6 issue 3, pp. 396-400, 2009.

[5] Omar, R.; Rahim, N.A., "Modeling and simulation for voltage sags/swells mitigation using dynamic voltage restorer (DVR), "Power Engineering Conference, 2008. AUPEC '08. Australasian Universities, vol.1, no.5, pp. 14-17, Dec. 2008.

[6] Bollen, M. H. J., "Understanding power quality problems" Vol. 3. New York: IEEE press, 2000.

[7] Hingorani, N.G., "Introducing custom power," Spectrum, IEEE , vol.32, no.6, pp.41,48, June 1995.

[8] Pakharia, A., Gupta, M, "Dynamic Voltage Restorer for Compensation of Voltage Sag and Swell: A Literature Review", International Journal of Advance in Engineering \& Technology, vol 4, issue 1, pp. 347-355, july 2012.

[9] Stones, J., \& Collinson, A., "Power quality," Power Eng. Journal, vol.15, no.2, pp.58-64, April 2001.

[10] Bollen, M. H. J., "What is power quality?" Electric Power Systems Research, vol.66, no.1, pp.5-14, July 2003.

[11] El Mofty, A.; Youssef, K., "Industrial power quality problems," Electricity Distribution, 2001. Part 1: Contributions. CIRED. 16th International Conference and Exhibition on (IEE Conf. Publ No. 482), vol.2, no., pp.5 2001.

[12] Reid, W.E., "Power quality issues-standards and guidelines," Industry Applications, IEEE Transactions on, vol.32, no.3, pp.625-632, May/Jun 1996

[13] Ghosh, A., \& Ledwich, G. F., "Power Quality Enhancement Using Custom Power Devices", Kluwer Academic Publishers, 2002.

[14] Pal, Y.; Swarup, A.; Singh, B., "A Review of Compensating Type Custom Power Devices for Power Quality Improvement," Power System Technology and IEEE Power India Conference, 2008. POWERCON 2008. Joint International Conference on, vol.1, no.8, pp.12-15, Oct. 2008.

[15] Chang, C.S.; Ho, Y.S.; Loh, P.C., "Voltage quality enhancement with power electronics based devices," Power Engineering Society Winter Meeting, 2000. IEEE, vol.4, no., pp.2937-2942 vol.4, 2000.

[16] Ghosh, H., Shah, P. K., \& Panda, G. K., “ Design and Simulation of a Novel Self Supported Dynamic Voltage Restorer (DVR) for Power Quality Improvement”, International Journal of Scientific \& Engineering Research, vol. 3, issue 6, pp 1-6, june2012.

[17] McHattie, R., "Dynamic voltage restorer the customers's perspective," Dynamic Voltage Restorers Replacing Those Missing Cycles (Digest No. 1998/189), IEE Half Day Colloquium on, vol., no., pp.1/1,1/5, 11 Feb 1998.

[18] Bhaskar, M.A.; Dash, S.S.; Subramani, C.; Kumar, M.J.; Giresh, P.R.; Kumar, M.V., "Voltage Quality Improvement Using DVR," Recent Trends in Information, Telecommunication and Computing (ITC), 2010 International Conference on, vol., no., pp.378,380, 12-13 March 2010.

[19] Vasudevanaidu, P.; Tech, M.; Narendra Kumar, Y., "A new simple modeling and analysis of custom power controllers," Power Systems, 2009. ICPS '09. International Conference on, vol., no., pp.1,6, 27-29 Dec. 2009

[20] Bhanoo, M.M., "Static transfer switch: advances in high speed solid-state transfer switches for critical power quality and reliability applications," Textile, Fiber and Film Industry Technical Conference, 1998 IEEE Annual, vol., no., pp.5/1,5/8, 5-7 May 1998

[21] Tandjaoui, M.N.; Benachaiba, C.; Abdelkhalek, O.; Doumbia, M.L.; Mouloudi, Y., "Sensitive loads voltage improvement using Dynamic Voltage Restorer," Electrical Engineering and Informatics (ICEEI), 2011 International Conference on, vol., no., pp.1,5, 17-19 July 2011

[22] Ramachandaramurthy, V.K.; Arulampalam, A.; Fitzer, C.; Zhan, C.; Barnes, M.; Jenkins, N., "Supervisory control of dynamic voltage restorers," Generation, Transmission and Distribution, IEE Proceedings- , vol.151, no.4, pp.509,516, 11 July 2004.

[23] Ghosh, A.; Ledwich, G., "Compensation of distribution system voltage using DVR," Power Delivery, IEEE Transactions on, vol.17, no.4, pp.1030-1036, Oct 2002.

[24] Posada, C.J.; Ramirez, J.M.; Correa, R.E., "Voltage compensation for common disturbances at the distribution level," Innovative Smart Grid Technologies (ISGT Latin America), 2011 IEEE PES Conference on, vol., no., pp.1,6, 19-21 Oct. 2011

[25] Woodley, N.H.; Morgan, L.; Sundaram, A., "Experience with an inverter-based dynamic voltage restorer," Power Delivery, IEEE Transactions on, vol.14, no.3, pp.1181-1186, Jul 1999. 
Electrical \& Computer Engineering: An International Journal (ECIJ) Volume 4, Number 2, June 2015

[26] Praveen, J.; Muni, B.P.; Venkateshwarlu, S.; Makthal, H.V., "Review of dynamic voltage restorer for power quality Improvement," Industrial Electronics Society, 2004. IECON 2004. 30th Annual Conference of IEEE, vol.1, no., pp.749-754 Vol. 1, 2-6 Nov. 2004.

[27] Yun Wei Li; Vilathgamuwa, D.M.; Blaabjerg, F.; Poh Chiang Loh, "A Robust Control Scheme for Medium-Voltage-Level DVR Implementation," Industrial Electronics, IEEE Transactions on, vol.54, no.4, pp.2249-2261, Aug. 2007.

[28] Omar, R., Rahim, N., \& Sulaiman, M., "Dynamic Voltage Restorer Application for Power Quality Improvement in Electrical Distribution System: An Overview" Australian Journal of Basic and Applied Sciences, vol. 5, no. 12, pp. 379-396, 2011.

[29] Vilathgamuwa, M.; Wijekoon, H.M., "Mitigating Zero Sequence Effects in Dynamic Voltage Restorers," Power Electronics Specialists Conference, 2007. PESC 2007. IEEE, vol., no., pp.30793085, 17-21 June 2007.

[30] Changjiang Zhan; Ramachandaramurthy, V.K.; Arulampalam, A.; Fitzer, C.; Kromlidis, S.; Barnes, M.; Jenkins, N., "Dynamic voltage restorer based on voltage space vector PWM control," Applied Power Electronics Conference and Exposition, 2001. APEC 2001. Sixteenth Annual IEEE, vol.2, no., pp.1301-1307 vol.2, 2001.

[31] Zhan, C.; Barnes, M.; Ramachandaramurthy, V.K.; Jenkins, N., "Dynamic voltage restorer with battery energy storage for voltage dip mitigation," Power Electronics and Variable Speed Drives, 2000. Eighth International Conference on (IEE Conf. Publ. No. 475), vol., no., pp.36-,365, 2000.

[32] Li, B.H.; Choi, S.S.; Vilathgamuwa, D.M., "On the injection transformer used in the dynamic voltage restorer," Power System Technology, 2000. Proceedings. PowerCon 2000. International Conference on , vol.2, no., pp.941-946 vol.2, 2000.

[33] Mahesh, S.S.; Mishra, M.K.; Kumar, B.K.; Jayashankar, V., "Rating and design issues of DVR injection transformer," Applied Power Electronics Conference and Exposition, 2008. APEC 2008. Twenty-Third Annual IEEE, vol., no., pp.449-455, 24-28 Feb. 2008.

[34] Nielsen, J.G.; Blaabjerg, F., "A detailed comparison of system topologies for dynamic voltage restorers," Industry Applications, IEEE Transactions on, vol.41, no.5, pp.1272-1280, Sept.-Oct. 2005.

[35] Kangarlu, M.F.; Babaei, E., "Determination of the transformer turns ratio in a DVR to reduce the switches voltage rating," Power Electronics and Drive Systems Technology (PEDSTC), $20123 r d$, vol., no., pp.315-318, 15-16 Feb. 2012.

[36] Ramachandaramurthy, V.K.; Fitzer, C.; Arulampalam, A.; Zhan, C.; Barnes, M.; Jenkins, N., "Control of a battery supported dynamic voltage restorer," Generation, Transmission and Distribution, IEE Proceedings- , vol.149, no.5, pp.533-542, Sep 2002.

[37] Babaei, Ebrahim, and Mohammad Farhadi Kangarlu. "Cross-phase voltage sag compensator for threephase distribution systems." International Journal of Electrical Power \& Energy Systems, vol.51, pp. 119-126, 2013.

[38] Kangarlu, M.F.; Hosseini, S.H.; Babaei, E.; Khoshkbar Sadigh, A., "Transformerless DVR topology based on multilevel inverter with reduced number of switches," Power Electronic \& Drive Systems \& Technologies Conference (PEDSTC), 2010 1st, vol., no., pp.371-375, 17-18 Feb. 2010.

[39] Roncero-Sanchez, P.; Acha, E., "Dynamic Voltage Restorer Based on Flying Capacitor Multilevel Converters Operated by Repetitive Control," Power Delivery, IEEE Transactions on, vol.24, no.2, pp.951-960, April 2009.

[40] Babaei, E.; Kangarlu, M.F.; Sabahi, M., "Dynamic voltage restorer based on multilevel inverter with adjustable dc-link voltage," Power Electronics, IET, vol.7, no.3, pp.576-590, March 2014.

[41] Mahmoud, A., El-Gammal, Amr Y. Abou-Ghazala and Tarek I. El-Shennawy," " Dynamic Voltage Restorer (DVR) for Voltage Sag Mitigation”,International Journal on Electrical Engineering and Informatics, vol.3, no.1, pp.1-11, march 2011.

[42] Al-Hadidi, H.K.; Gole, A.M.; Jacobson, D.A., "A Novel Configuration for a Cascade Inverter-Based Dynamic Voltage Restorer With Reduced Energy Storage Requirements," Power Delivery, IEEE Transactions on, vol.23, no.2, pp.881-888, April 2008.

[43] Hyosung Kim; Jang-Hwan Kim; Seung-Ki Sul, "A design consideration of output filters for dynamic voltage restorers," Power Electronics Specialists Conference, 2004. PESC 04. 2004 IEEE 35th Annual, vol.6, no., pp.4268-4272 Vol.6, 20-25 June 2004. 
Electrical \& Computer Engineering: An International Journal (ECIJ) Volume 4, Number 2, June 2015

[44] Choi, S.S.; Li, B.H.; Vilathgamuwa, D.M., "A comparative study of inverter and line-side filtering schemes in the dynamic voltage restorer," Power Engineering Society Winter Meeting, 2000. IEEE, vol.4, no., pp.2967-2972 vol.4, 2000.

[45] Choi, S. S.; Li, B. H.; Vilathgamuwa, D. M., "Design and Analysis of the Inverter-Side Filter Used in the Dynamic Voltage Restorer," Power Engineering Review, IEEE, vol.22, no.4, pp.80-80, April 2002.

[46] Choi, S.S.; Li, B.H.; Vilathgamuwa, D.M., "Design and analysis of the inverter-side filter used in the dynamic voltage restorer," Power Delivery, IEEE Transactions on, vol.17, no.3, pp.857-864, Jul 2002.

[47] Omar, R.; Rahim, N.A., "Power quality improvement in low voltage distribution system using Dynamic Voltage Restorer (DVR)," Industrial Electronics and Applications (ICIEA), 2010 the 5th IEEE Conference on , vol., no., pp.973-978, 15-17 June 2010.

[48] Fitzer, C.; Arulampalam, A.; Barnes, M.; Zurowski, Rainer, "Mitigation of saturation in dynamic voltage restorer connection transformers," Power Electronics, IEEE Transactions on, vol.17, no.6, pp.1058-1066, Nov 2002.

[49] Nielsen, J.G.; Blaabjerg, F.; Mohan, N., "Control strategies for dynamic voltage restorer compensating voltage sags with phase jump," Applied Power Electronics Conference and Exposition, 2001. APEC 2001. Sixteenth Annual IEEE, vol.2, pp.1267-1273, 2001.

[50] Sadigh, A.K.; Smedley, K.M., "Review of voltage compensation methods in dynamic voltage restorer (DVR)," Power and Energy Society General Meeting, 2012 IEEE, vol.1, no.8, pp. 22-26 July 2012.

[51] Hosseini, S.H.; Banaei, M.R., "A new minimal energy control of the DC link energy in four-wire dynamic voltage restorer," Industrial Electronics Society, 2004. IECON 2004. 30th Annual Conference of IEEE, vol.3, no., pp.3048-3053 Vol. 3, 2-6 Nov. 2004

[52] Banaei, M.R.; Nahavandi, A.; Hosseini, S.H., "Investigation of multi-functional DVR to improve power quality characteristic," Electrical Engineering/Electronics, Computer, Telecommunications and Information Technology, 2009. ECTI-CON 2009. 6th International Conference on, vol.01, no., pp.144-149, 6-9 May 2009

[53] Abdollahzadeh, Hamed, Mostafa Jazaeri, and Arash Tavighi. "A new fast-converged estimation approach for Dynamic Voltage Restorer (DVR) to compensate voltage sags in waveform distortion conditions." International Journal of Electrical Power \& Energy Systems vol. 54, pp. 598-609, 2014.

[54] Taghikhani, M. A., "Phase Advanced Dynamic Voltage Restorer Control System Design", International Journal of Control Science and Engineering, Vol. 2, No. 4, pp. 60-68, 2012.

[55] Jun Tan; Xinchun Lin; Yuping Duan; Jun Qiu, "Optimized control for a DVR to compensate long duration voltage sag with low distortion at the load," Electrical and Control Engineering (ICECE), 2011 International Conference on , vol., no., pp.2414-2417, 16-18 Sept. 2011.

[56] Choi, S.S.; Li, B.H.; Vilathgamuwa, D.M., "Dynamic voltage restoration with minimum energy injection," Power Systems, IEEE Transactions on, vol.15, no.1, pp.51-57, Feb 2000.

[57] Vilathgamuwa, D.M.; Wijekoon, H.M.; Choi, S.S., "A Novel Technique to Compensate Voltage Sags in Multiline Distribution System;The Interline Dynamic Voltage Restorer," Industrial Electronics, IEEE Transactions on, vol.53, no.5, pp.1603-1611, Oct. 2006.

[58] Vilathgamuwa, D. M.; Perera, A. A. D. R.; Choi, S. S., "Voltage Sag Compensation with Energy Optimized Dynamic Voltage Restorer," Power Engineering Review, IEEE, vol.22, no.10, pp.63-63, Oct. 2002.

[59] Fitzer, C.; Barnes, M.; Green, P., "Voltage sag detection technique for a dynamic voltage restorer," Industry Applications, IEEE Transactions on , vol.40, no.1, pp.203-212, Jan.-Feb. 2004.

[60] Fitzer, C.; Barnes, M.; Green, P., "Voltage sag detection technique for a dynamic voltage restorer," Industry Applications Conference, 2002. 37th IAS Annual Meeting. Conference Record of the , vol.2, no., pp.917-924 vol.2, 13-18 Oct. 2002.

[61] Suma, J.; Mishra, M.K., "Instantaneous symmetrical component theory based algorithm for characterization of three phase distorted and unbalanced voltage sags," Industrial Technology (ICIT), 2013 IEEE International Conference on , vol., no., pp.845-850, 25-28 Feb. 2013.

[62] J. G. Nielsen, M. Newman, H. Nielsen, and F. Blaabjerg, "Control and testing of a dynamic voltage restorer (DVR) at medium voltage level,” IEEE Trans. Power Electron., vol. 19, no. 3, pp. 806-813, May 2004. 
Electrical \& Computer Engineering: An International Journal (ECIJ) Volume 4, Number 2, June 2015

[63] Bae, B.; Lee, J.; Jeong, J.; Han, B., "Line-Interactive Single-Phase Dynamic Voltage Restorer With Novel Sag Detection Algorithm," Power Delivery, IEEE Transactions on, vol.25, no.4, pp.27022709, Oct. 2010.

[64] Jeong, J.; Han, B., "Development of line-interactive dynamic voltage restorer with hybrid sag detection," Power and Energy Society General Meeting, 2010 IEEE, vol., no., pp.1-7, 25-29 July 2010.

[65] Han, B.; Bae, B.; Lee, J.; Lee, H., "Algorithm for rapid detection of voltage disturbance in dynamic voltage restorer," Power and Energy Society General Meeting - Conversion and Delivery of Electrical Energy in the 21st Century, 2008 IEEE, vol., no., pp.1-6, 20-24 July 2008.

[66] Saleh, S.A.; Rahman, M.A., "Wavelet-based dynamic voltage restorer for power quality improvement," Power Electronics Specialists Conference, 2004. PESC 04. 2004 IEEE 35th Annual, vol.4, no., pp.3152-3156 Vol.4, 2004.

[67] Saleh, S.A.; Rahman, M.A., "Real-Time Implementation and Testing of a Wavelet-Controlled Dynamic Voltage Restorer," Industry Applications Conference, 2006. 41st IAS Annual Meeting. Conference Record of the 2006 IEEE, vol.2, no., pp.733-740, 8-12 Oct. 2006.

[68] Barros, Julio, Ramón I. Diego, and Matilde De Apraiz. "Applications of wavelets in electric power quality: Voltage events." Electric Power Systems Research vol.88, pp. 130-136, 2012.

[69] Young-Hoon Cho; Seung-Ki Sul, "Controller design for dynamic voltage restorer with harmonics compensation function," Industry Applications Conference, 2004. 39th IAS Annual Meeting. Conference Record of the 2004 IEEE, vol.3, no., pp.1452-1457 vol.3, 3-7 Oct. 2004.

[70] Wang Jing; Xu Aiqin; Shen Yueyue, "A survey on control strategies of dynamic voltage restorer," Harmonics and Quality of Power, 2008. ICHQP 2008. 13th International Conference on, vol., no., pp.1-5, Sept. 28 2008-Oct. 12008.

[71] Bayindir, K.Q.; Teke, A.; Tumay, M., "A robust control of dynamic voltage restorer using fuzzy logic," Electrical Machines and Power Electronics, 2007. ACEMP '07. International Aegean Conference on, vol., no., pp.55-60, 10-12 Sept. 2007.

[72] Srisailam, C. H., and A. Sreenivas. "Mitigation of voltage sags/swells by dynamic voltage restorer using PI and fuzzy logic controller." International Journal of Engineering Research and Applications, vol. 2, no. 4, pp.1733-1737, 2012.

[73] Sundarabalan, C. K., and K. Selvi. "Compensation of voltage disturbances using PEMFC supported Dynamic Voltage Restorer." International Journal of Electrical Power \& Energy Systems, vol. 71, pp.77-92, 2015.

[74] Jurado, F., "Neural network control for dynamic voltage restorer," Industrial Electronics, IEEE Transactions on , vol.51, no.3, pp.727-729, June 2004.

[75] Omar, R.; Rahim, N.A., "Implementation and control of a dynamic voltage restorer using Space Vector Pulse Width Modulation (SVPWM) for voltage sag mitigation," Technical Postgraduates (TECHPOS), 2009 International Conference for, vol., no., pp.1-6, 14-15 Dec. 2009.

[76] Omar, R.; Rahim, N.A., "New control technique applied in dynamic voltage restorer for voltage sag mitigation," Industrial Electronics and Applications, 2009. ICIEA 2009. 4th IEEE Conference on, vol., no., pp.848-852, 25-27 May 2009.

[77] Changjiang Zhan; Ramachandaramurthy, V.K.; Arulampalam, A.; Fitzer, C.; Kromlidis, S.; Bames, M.; Jenkins, N., "Dynamic voltage restorer based on voltage-space-vector PWM control," Industry Applications, IEEE Transactions on, vol.37, no.6, pp.1855-1863, Nov/Dec 2001.

[78] Wijekoon, H.M.; Vilathgamuwa, D.M.; Choi, S.S., "Interline dynamic voltage restorer: an economical way to improve interline power quality," Generation, Transmission and Distribution, IEE Proceedings- , vol.150, no.5, pp.513-520, 15 Sept. 2003.

[79] Moradlou, M.; Karshenas, H.R., "Design Strategy for Optimum Rating Selection of Interline DVR," Power Delivery, IEEE Transactions on , vol.26, no.1, pp.242-249, Jan. 2011.

[80] Karshenas, H.R.; Moradlou, M., "Design strategy for optimum rating selection in interline DVR," Electrical and Computer Engineering, 2008. CCECE 2008. Canadian Conference on, vol., no., pp.1919-1924, 4-7 May 2008.

[81] Dhas, G.J.S.; Prakash, T.R.D., "A novel approach for voltage sag mitigation using facts device interline dynamic voltage restorer," Electronics Computer Technology (ICECT), $20113 \mathrm{rd}$ International Conference on, vol.4, no., pp.37-41, 8-10 April 2011. 
Electrical \& Computer Engineering: An International Journal (ECIJ) Volume 4, Number 2, June 2015

[82] Usha, R. P., R. Sudha, and S. Rama Reddy. "Voltage sag/swell compensation in an interline dynamic voltage restorer." In Emerging Trends in Electrical and Computer Technology (ICETECT), 2011 International Conference on, pp. 309-314. IEEE, 2011.

[83] Elserougi, A.; Abdel-Khalik, A.S.; Ahmed, S.; Massoud, A., "Active and reactive power management of photovoltaic-based interline dynamic voltage restorer in low voltage distribution networks," Energy Conversion Congress and Exposition (ECCE), 2012 IEEE, vol., no., pp.3098,3104, 15-20 Sept. 2012.

[84] Hossam-Eldin, A.; Elserougi, A., "Renewable energy fed interline DVR for voltage sag mitigation in distribution grids," Electricity Distribution (CIRED 2013), 22nd International Conference and Exhibition on, vol., no., pp.1,4, 10-13 June 2013.

[85] Vilathgamuwa, D.M.; Wijekoon, H.M.; Choi, S.S., "Interline dynamic voltage restorer: a novel and economical approach for multiline power quality compensation," Industry Applications, IEEE Transactions on, vol.40, no.6, pp.1678,-685, Nov.-Dec. 2004.

[86] Li, B.H.; Choi, S.S.; Vilathgamuwa, D.M., "Transformerless dynamic voltage restorer," Generation, Transmission and Distribution, IEE Proceedings- , vol.149, no.3, pp.263-273, May 2002.

[87] Sng, E.K.K.; Choi, S.S.; Vilathgamuwa, D.M., "Analysis of series compensation and DC-link voltage controls of a transformerless self-charging dynamic voltage restorer," Power Delivery, IEEE Transactions on, vol.19, no.3, pp.1511-1518, July 2004.

[88] Babaei, E.; Kangarlu, M.F., "Voltage quality improvement by a dynamic voltage restorer based on a direct three-phase converter with fictitious DC link," Generation, Transmission \& Distribution, IET, vol.5, no.8, pp.814-823, August 2011.

[89] Babaei, E.; Kangarlu, M.F.; Sabahi, M., "Mitigation of Voltage Disturbances Using Dynamic Voltage Restorer Based on Direct Converters," Power Delivery, IEEE Transactions on , vol.25, no.4, pp.26762683, Oct. 2010.

[90] Jothibasu, S.; Mishra, M.K., "A AC-AC converter based topology for mitigation of voltage sag with phase jump," Industrial and Information Systems (ICIIS), 2013 8th IEEE International Conference on , vol., no., pp.259-264, 17-20 Dec. 2013.

[91] Ramirez, J.M.; Garcia-Vite, P.; Lozano, J.M.; Mancilla-David, F., "Dynamic voltage restorers based on AC-AC topologies," Power and Energy Society General Meeting, 2012 IEEE, vol., no., pp.1-7, 22-26 July 2012.

[92] Jothibasu, S.; Mishra, M.K., "An Improved Direct AC-AC Converter for Voltage Sag Mitigation," Industrial Electronics, IEEE Transactions on, vol.62, no.1, pp.21-29, Jan. 2015.

[93] Babaei, E.; Kangarlu, M.F., "A new topology for dynamic voltage restorers without dc link," Industrial Electronics \& Applications, 2009. ISIEA 2009. IEEE Symposium on, vol.2, no., pp.1016-1021, 4-6 Oct. 2009

[94] Lozano, J.M.; Ramirez, J.M.; Correa, R.E., "A novel Dynamic Voltage Restorer based on matrix converters," Modern Electric Power Systems (MEPS), 2010 Proceedings of the International Symposium, vol., no., pp.1,7, 20-22 Sept. 2010.

[95] Lozano, J.M.; Hernandez-Figueroa, M.A.; Ramirez, J.M., "An operative comparison of two DVR topologies based on a matrix converter without energy storage," IECON 2012 - 38th Annual Conference on IEEE Industrial Electronics Society, vol., no., pp.6050-6056, 25-28 Oct. 2012.

[96] Garcia-Vite, P.M.; Mancilla-David, F.; Ramirez, J.M., "Dynamic modeling and control of an AC-link dynamic voltage restorer," Industrial Electronics (ISIE), 2011 IEEE International Symposium on, vol., no., pp.1615-1620, 27-30 June 2011

[97] Jothibasu, S.; Mishra, M.K., "A Control Scheme for Storageless DVR Based on Characterization of Voltage Sags," Power Delivery, IEEE Transactions on, vol.29, no.5, pp.2261-2269, Oct. 2014.

[98] Garcia-Vite, P.M.; Mancilla-David, F.; Ramirez, J.M., "A Dynamic Voltage Restorer based on vectorswitching matrix converters," Industrial Technology (ICIT), 2010 IEEE International Conference on, vol., no., pp.637-642, 14-17 March 2010. 